Pediat. Res. 4: 328-336 (1970)

Developmental

biochemistry

cytochrome oxidase enzyme activity

liver

malate dehydrogenase

mitochondria

\title{
Perinatal Regulation of Mitochondrial and Cytoplasmic Enzymes in Rabbit Liver
}

\author{
Garl Hugh Smith ${ }^{[45]}$ \\ Department of Pathology, Washington University School of Medicine, St. Louis, Missouri, USA
}

Extract

The control of postnatal development of the activities of cytoplasmic and mitochondrial malate dehydrogenases and of the purely mitochondrial enzyme, cytochrome oxidase, has been studied in rabbit liver. Each of the three enzymes increased 1.6-1.8-fold in activity during the first 2 days of life. Delivery of animals at varying stages of maturation demonstrated (table II) that the increase in all cases occurred when delivery was effected and was a result of some aspect of the process of birth itself.

Maturation affects cytoplasmic malate dehydrogenase (MDH) differently than the two mitochondrial enzymes. Cytoplasmic $\mathrm{MDH}$ is relatively constant in activity in utero and increases approximately $80 \%$ whenever delivery is effected (table II, figure 1). In contrast, both the mitochondrial enzymes decrease $40 \%$ in activity if animals remain in utero beyond normal term. Their increase $(20-40 \%)$ following premature delivery is considerably smaller than the large (1.5-fold) increase following postmature delivery.

Using the artificial feeding procedure developed for this study, newborn animals were maintained for $48 \mathrm{~h}$ in an hypoxic environment. Preliminary results suggested that development of enzyme activity was affected by hypoxia.

\section{Speculation}

Normal alterations in perinatal enzyme activity are probably a result of various aspects of maturation and the birth process. Varying the time of delivery and the extrauterine environment makes possible experimental study of the physiologic control of this and other perinatal processes.

\section{Introduction}

The perinatal period is marked by changes in the biologic and chemical environment of the newborn. Endocrinologic alterations and changes in oxygen tension, carbohydrate, and protein metabolism occur $[5,9]$. These are accompanied by change in the chemical and enzymatic composition of tissue [3, 6-9, 19,
$21,22,27]$. In some instances, alterations in enzymatic activities occur as a response to the process of birth itself $[19,21,35,36]$, whereas in others, phenomena involving some aspect of tissue maturation occur [22]. The completion of such alterations would seem important to healthy survival in the extrauterine environment.

Previous work in this laboratory has demonstrated 
that total malate dehydrogenase (L-malate: NAD oxidoreductase, EC.1.1.1.37) (MDH) activity increases in the immediate postnatal period in rabbit liver [25]. Delivering animals artificially at varying stages of maturation showed that the increase, occurring at the time delivery was effected, was a response to the process of birth itself. In other studies $[12,14,15,32$, 33, 35-37], differing physiologic processes associated with birth have been shown to affect perinatal changes in activities of various enzymes and it was, therefore, of interest to clarify the nature of the alteration in $\mathrm{MDH}$ activity and study its control.

Malate dehydrogenase exists as isoenzymes; some are found in the mitochondria and others are in the cytoplasm $[16,34]$. Since these isoenzymes are different proteins with different kinetic properties and different metabolic roles, it was desirable to study their regulation by both birth and tissue maturation separately.

This paper describes a study of the developmental control of mitochondrial and soluble $\mathrm{MDH}$ and of a purely mitochondrial oxidative enzyme: cytochrome oxidase (cytochrome $c: \mathrm{O}_{2}$ oxidoreductase, EG.1.9.3.1). The finding that activity of mitochondrial enzymes could be altered by birth itself suggested that normal perinatal variation in oxygen tension might play a role in regulation. Accordingly, a preliminary study was undertaken using the technique of artificial feeding previously developed, to determine the role of environmental oxygen tension in regulation of enzyme activity.

\section{Materials and Methods}

\section{Preparation of Animals and Tissues}

New Zealand white rabbits were bred, delivered, and fed artificially for 2 days following birth by a procedure which has been described in detail [25]. Chorionic gonadotrophin was administered to all pregnant females regardless of the intended ultimate length of gestation. Fetuses were delivered by cesarean section 29-33 days following breeding. They were maintained in vigorous condition following birth by periodic feeding with a mixture of milk and corn oil given through an indwelling orogastric tube.

The animals in reduced oxygen concentrations were kept in a closed box with rubber sleeve arm ports. Air and nitrogen were introduced to give the desired oxygen concentration (usually 6-7\%), which was monitored with anoxygen analyzer [39]. The nitrogen was bubbled through water to give a relative humidity in the chamber of approximately $60 \%$.

With the gas mixture established, a segment of a gravid uterus was removed and placed in the chamber. Using the sleeve ports, fetuses were delivered directly into the artificial atmosphere. They were intubated and fed using the ports and thus spent their entire postpartum life in the hypoxic atmosphere. After $48 \mathrm{~h}$, they were removed from the chamber and killed.

\section{Enzyme and Protein Determinations}

Cytochrome oxidase was assayed spectrophotometrically by the procedure of SMrTH [26]. Tissue homogenates or cell fractions were diluted 10 -fold into a solution containing $1 \mathrm{mg} / \mathrm{ml}$ sodium deoxycholate, $0.1 \%$ bovine albumin, and $0.33 \mathrm{~m}$ sucrose in $0.01 \mathrm{~m}$ potassium phosphate, $\mathrm{pH}$ 7.0. This mixture was found to give optimal release of activity which was then stable for approximately $1 \mathrm{~h}$. A suitable volume was added to reduced cytochrome $c$ in $0.1 \mathrm{~m}$ potassium phosphate, $\mathrm{pH} 7.0$, and incubated at $25^{\circ}$. Cytochrome $c$ [40] was reduced with ascorbic acid [31], and the amount used in the assay was regulated so that the absorption of the substrate mixture at $550 \mathrm{~m} \mu$ was approximately 0.700 when fully reduced with ascorbic acid. The concentration of cytochrome $c$ was determined using this absorption value and the known molar extinction coefficient [23]. This concentration (approximately 38 $\mathrm{mm}$ ) was used to calculate the specific activity of cytochrome oxidase [31], which was expressed as micromoles per minute per gram total tissue protein. Activity was proportional to tissue concentration. Malate dehydrogenase and protein were determined as in a previous study [25].

\section{Tissue Fractionation}

Livers were homogénized $2-3 \mathrm{~min}$ in an ice-cooled homogenizer with a conical Teflon pestle motor driven at $300 \mathrm{rpm}$. Approximately five tissue volumes of 0.33 M sucrose were used during homogenization, and the initial homogenate was then diluted twofold for centrifugal fractionation. Tissues were fractionated by modification of a standard method [13]. The homogenate was initially centrifuged $10 \mathrm{~min}$ at $2,250 \mathrm{rpm}$ $(475 \times g)$. The resulting nuclear fraction was washed twice by resuspension in 2-4 volumes of the same sucrose solution followed by centrifugation at the same speed. The initial supernate was combined with those from these two washes and recentrifuged $15 \mathrm{~min}$ at $9,500 \mathrm{rpm}(8,300 \times g)$ to precipitate the mitochondrial fraction. This was washed once with sucrose solution and resedimented under the same conditions. The supernatant solution combined with the supernate from this wash was centrifuged at $39,000 \mathrm{rpm}(100,000$ $\times g$ ) to yield the microsomal fraction precipitate and a final supernatant solution. The initial two centrifugation steps were conducted in a standard refrigerated centrifuge [41]; the final step occurred in an ultracentrifuge [42]. Gravity values are average forces calculated for the center of the tube. The three pre- 
cipitated fractions were rehomogenized with a small hand-operated glass tissue grinder in approximately 4 volumes of $0.33 \mathrm{~m}$ sucrose in $0.01 \mathrm{~m}$ potassium phosphate, $\mathrm{pH} 7.4$, and stored at $-85^{\circ}$ in multiple small tubes suitable for individual enzyme assays. Aliquots of the initial homogenate and of the supernatant solutions from the various steps were similarly stored. Cytochrome oxidase and MDH activities were stable for 8 months or longer.

\section{Ultrastructure of Fractions and Enzyme Distribution}

Portions of each of the three fractions were fixed in $5 \%$ glutaraldehyde in Millonig's phosphate buffer. After dehydration through graded methyl alcohol solutions, they were embedded in Epon-Araldite, stained with uranyl acetate and lead citrate, and examined by electron microscopy. The nuclear fraction consisted of intact parenchymal and probably hematopoietic cells, nuclei, and red blood cells. The mitochondrial fraction contained lysosomes, smooth and rough microsomes, free ribosomal particles, as well as mitochondria. Most mitochondria had an intact double membrane and a distinct cristal pattern, but appeared somewhat swollen. They comprised from 40 to $70 \%$ of the fraction. The microsomal fraction contained some mitochondria and large amounts of microsomal and other membranous material.

Cytochrome oxidase activity was measured in all fractions from some of the homogenates. Activity was distributed as follows: nuclear fraction, 25-45\%; mitochondrial fraction, $35-65 \%$; microsomal fraction, $10-15 \%$; final supernatant, $0-2 \%$. Recovery was usually $85-90 \%$ or greater.

\section{Enzyme Assays of Fractions}

Cytochrome oxidase and $\mathrm{MDH}$ activities were measured in the original homogenates and the mitochondrial fractions of all livers. Activity was calculated per gram of original homogenate protein using the volumes measured during fractionation and the measured protein content of the homogenate. The values expressed in the tables concerning cytochrome oxidase and total $\mathrm{MDH}$ activities are those measured in homogenates.

Recovery of mitochondria in homogenization and fractionation was variable, and ranged from about 35 to $70 \%$. To calculate the total mitochondrial $\mathrm{MDH}$ activity in any given tissue it was necessary to correct for this variability. Since all cytochrome oxidase could be expected to be in mitochondria [38], the ratio of homogenate cytochrome oxidase activity to mitochondrial fraction cytochrome oxidase activity could be taken as an index of the recovery of mitochondria in any given fractionation. The MDH activity of the mitochondial fraction was corrected for partial re- covery by multiplying it by this ratio determined for that particular organ fractionation. The corrected value is listed in the tables as mitochondial $\mathrm{MDH}$.

Two assumptions are inherent in this procedure: 1) all the $\mathrm{MDH}$ activity of the mitochondrial fraction must be in mitochondria; and 2) the ratio of cytochrome oxidase to $\mathrm{MDH}$ activity in the mitochondria sedimenting with the mitochondrial fraction must be the same as that in mitochondria not sedimenting with the fraction. Mitochondria are apparently the only cytoplasmic particles to contain a malate dehydrogenase. The MDH activity in microsomes is extremely low and no activity has been reported in lysosomes [2, $10,24]$, the two other principal components of the mitochondrial fraction. The first assumption thus appears valid.

With regard to the second assumption, there is apparently conflicting evidence as to whether types of mitochondria with differing relative amounts of cytochrome oxidase and $\mathrm{MDH}$ exist in liver $[1,30]$. The fractionation procedure in this study, however, was designed to prepare a broad representative group of mitochondria and include the range of weight classes reported $[1,30]$. The bulk of the remaining cytochrome oxidase activity is in the nuclear fraction and is presumably contained in intact cells contaminating this fraction. To check the second assumption further, a subfraction was prepared by centrifuging the postmitochondrial supernatant an additional $30 \mathrm{~min}$ at 9,500 rpm. This subfraction contained cytochrome oxidase activity equivalent to approximately $10 \%$ of the mitochondrial fraction. The ratio of activity of cytochrome oxidase to $\mathrm{MDH}$ in it was within $30 \%$ of that of the main mitochondrial fraction. Therefore, the procedure employed appears reasonable for the calculations used in this study.

The residual $\mathrm{MDH}$ activity, calculated by subtracting the mitochondrial from the total of the homogenate, has been termed cytoplasmic or soluble. A small portion of this activity probably is actually in nuclei; however, $\mathrm{MDH}$ isoenzyme proteins of the nucleus are probably the same as the soluble ones of the cytoplasm [24].

\section{Results}

\section{Tissue Weight and Protein Content}

In the present study, enzyme activity has been expressed per unit tissue protein in the belief that this form offers the most meaningful basis for comparison of different groups of animals. For reference, liver content and liver and body weights of animals are given in table I. The protein of the mitochondrial fraction comprised from 7.5 to $11.5 \%$ of total liver 
protein and showed no systematic variation with maturation or postnatal age. With the procedures employed, which were designed to measure mitochondrial enzyme activity, it was not possible to determine and compare meaningfully the actual protein content of mitochondria of livers of different animals.

\section{Perinatal Enzyme Activity}

Malate dehydrogenase activities are given in table II and illustrated in figure 1 . As reported in a previous study [25], total activity rose about $70 \%$ during the $48 \mathrm{~h}$ following birth. Since the increase occurred following either premature or postmature delivery, it

Table I. Body weight and tissue composition

\begin{tabular}{|c|c|c|c|c|c|c|}
\hline \multirow{2}{*}{$\begin{array}{l}\text { Gestational } \\
\text { age, day }\end{array}$} & \multicolumn{2}{|c|}{ Body wt, $g$} & \multicolumn{2}{|c|}{ Liver wt, $\mathrm{g}$} & \multicolumn{2}{|c|}{ Liver protein content, $\%$ wet wt } \\
\hline & Birth & $48 \mathrm{~h}$ & Birth & $48 \mathrm{~h}$ & Birth & $48 \mathrm{~h}$ \\
\hline 29 & $\begin{array}{c}33.7 \pm 2.7^{1} \\
(7 / 2)^{2}\end{array}$ & $\begin{array}{c}39.6 \pm 2.6 \\
(11 / 4)\end{array}$ & $\begin{array}{c}2.10 \pm 0.46 \\
(4 / 1)\end{array}$ & $\begin{array}{c}1.35 \pm 0.10 \\
(4 / 1)\end{array}$ & $\begin{array}{c}12.19 \pm 0.48 \\
(10 / 3)\end{array}$ & $\begin{array}{c}16.90 \pm 0.64 \\
(11 / 4)\end{array}$ \\
\hline 31 & $\begin{array}{c}50.5 \pm 4.6 \\
(10 / 4)\end{array}$ & $\begin{array}{c}49.5 \pm 4.1 \\
(13 / 4)\end{array}$ & $\begin{array}{c}2.98 \pm 0.25 \\
(5 / 2)\end{array}$ & $\begin{array}{c}1.84 \pm 0.15 \\
(7 / 2)\end{array}$ & $\begin{array}{c}12.04 \pm 0.73 \\
(9 / 4)\end{array}$ & $\begin{array}{c}15.45 \pm 0.42 \\
(13 / 4)\end{array}$ \\
\hline 33 & $\begin{array}{c}48.5 \pm 2.9 \\
(9 / 3)\end{array}$ & $\begin{array}{c}59.7 \pm 3.5 \\
(12 / 4)\end{array}$ & $\begin{array}{c}3.45 \pm 0.18 \\
(4 / 1)\end{array}$ & $\begin{array}{c}2.00 \pm 0.22 \\
(6 / 2)\end{array}$ & $\begin{array}{c}13.62 \pm 0.48 \\
(9 / 3)\end{array}$ & $\begin{array}{c}17.90 \pm 0.61 \\
(12 / 4)\end{array}$ \\
\hline $\begin{array}{l}33 \text { Hypoxic } \\
\text { Adult }\end{array}$ & - & $\begin{array}{c}55.3 \pm 6.8 \\
(4 / 2)\end{array}$ & - & $\begin{array}{c}2.37 \pm 0.33 \\
(4 / 2)\end{array}$ & 14.8 & $\begin{array}{l}17.28 \pm 0.66 \\
\quad(4 / 2) \\
0.68\end{array}$ \\
\hline
\end{tabular}

1 Values are mean \pm SEM.

2 Numbers in parentheses are number of animals/number of litters.

Table II. Malate dehydrogenase ${ }^{1}$

\begin{tabular}{|c|c|c|c|c|c|c|}
\hline \multirow{2}{*}{$\begin{array}{l}\text { Gestational age, } \\
\text { day }\end{array}$} & \multicolumn{2}{|c|}{ Total } & \multicolumn{2}{|c|}{ Gytoplasm } & \multicolumn{2}{|c|}{ Mitochondria } \\
\hline & Birth & $48 \mathrm{~h}^{2}$ & Birth & $48 h^{2}$ & Birth & $48 h^{2}$ \\
\hline 29 & $\begin{array}{l}2155 \pm 70^{3} \\
(10 / 3)^{5}\end{array}$ & $\begin{array}{l}3545 \pm 125 \\
(11 / 4)\end{array}$ & $\begin{array}{c}1155 \pm 90 \\
(10 / 3)\end{array}$ & $\begin{array}{l}2370 \pm 110 \\
(11 / 4)\end{array}$ & $\begin{array}{c}1010 \pm 61 \\
(10 / 3)\end{array}$ & $\begin{array}{l}1180 \pm 75^{4} \\
(11 / 4)\end{array}$ \\
\hline 31 & $\begin{array}{c}2325 \pm 68 \\
(10 / 4)\end{array}$ & $\begin{array}{c}3695 \pm 90 \\
(13 / 4)\end{array}$ & $\begin{array}{l}1305 \pm 110 \\
(10 / 4)\end{array}$ & $\begin{array}{c}2270 \pm 90 \\
(12 / 4)\end{array}$ & $\begin{array}{l}1020 \pm 90^{6} \\
(10 / 4)\end{array}$ & $\begin{array}{l}1420 \pm 130 \\
(12 / 4)\end{array}$ \\
\hline 33 & $\begin{array}{c}2150 \pm 75 \\
(9 / 3)\end{array}$ & $\begin{array}{c}3930 \pm 145 \\
(10 / 5)\end{array}$ & $\begin{array}{l}1495 \pm 120 \\
(8 / 3)\end{array}$ & $\begin{array}{c}2300 \pm 115 \\
(9 / 5)\end{array}$ & $\begin{array}{l}665 \pm 50^{6} \\
(8 / 3)\end{array}$ & $\begin{array}{l}1680 \pm 150^{4} \\
(9 / 5)\end{array}$ \\
\hline Adult & \multicolumn{2}{|c|}{$2540 \pm 125$} & \multicolumn{2}{|c|}{$\begin{array}{c}1400 \pm 120 \\
(2)\end{array}$} & \multicolumn{2}{|c|}{$\begin{array}{c}1140 \pm 25 \\
(2)\end{array}$} \\
\hline
\end{tabular}

1 Activity in micromoles per minute per gram total tissue protein.

${ }^{2}$ All activities at $48 \mathrm{~h}$ are greater than activities in newborn animals of any gestational age $(P<0.001)$ with the exception of mitochondrial activity in 31-day animals for which $P<0.05$ and mitochondrial activity in 29-day animals which are not significantly greater than newborn.

3 Values are mean \pm sem.

${ }^{4}$ In animals of 33 days gestation, the mitochondrial activity at $48 \mathrm{~h}$ and the change in activity following delivery are greater than the corresponding values in 29-day animals $(p<0.01)$.

5 Numbers in parentheses are number of animals/number of litters.

${ }^{6}$ Mitochondrial activity at birth in animals of 33 days gestation is less than activity at birth in animals of 31 days gestation $(P<0.01)$. 


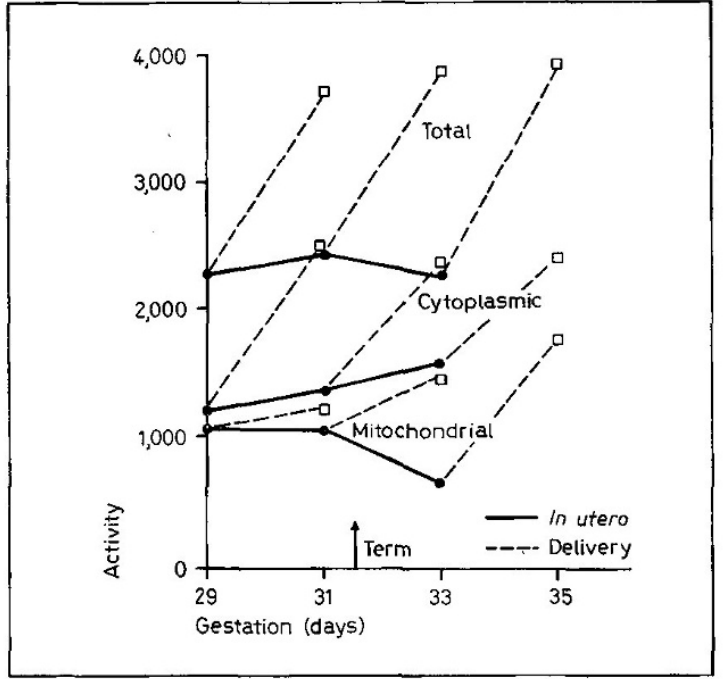

Fig.1. Total and cell component activities of malate dehydrogenase. Units of activity are micromoles per minute per gram total tissue protein.

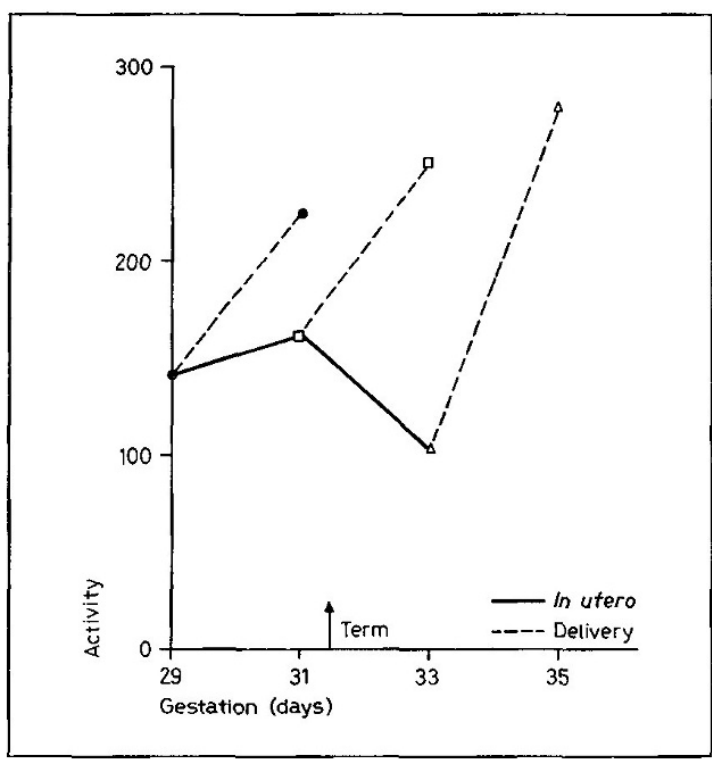

Fig. 2. Cytochrome oxidase activity. Units of activity are micromoles per minute per gram total tissue protein.

Fig. 3. Liver of hypoxic animal (A) and control (B). Note focal cytoplasmic vacuolation with predominantly pericentral distribution. Small round tubular structures are central veins. Hematoxylin and eosin. $\times 150$.
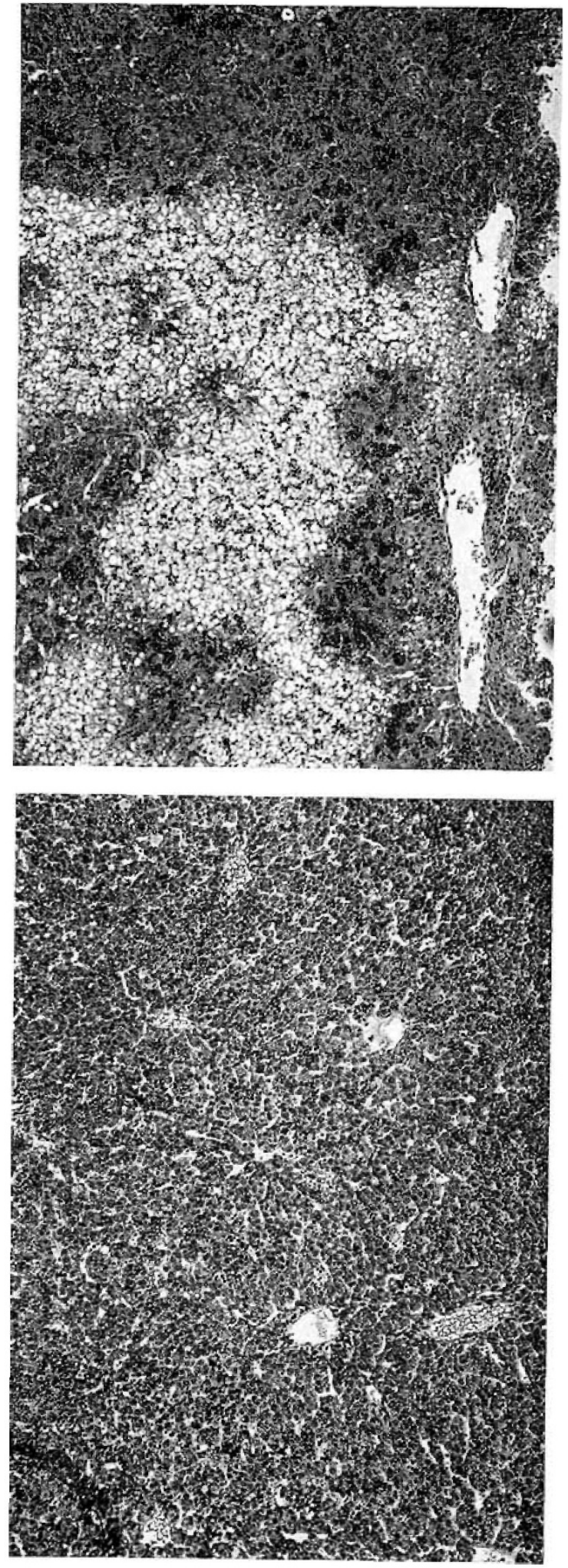
was seen as a response to the process of birth itself. Both the mitochondrial and the soluble activities increased in the newborn period. In both instances, the rise occurred following delivery at whatever stage of maturation it was effected.

The pattern of increase of the two MDH components was different. The cytoplasmic activity measured immediately at birth remained constant or increased slightly from 29 to 33 days as the animal remained in utero. The increase following delivery was of the same magnitude regardless of when delivery was effected. Mitochondrial activity was constant from 29 to 31 days in utero, but then fell approximately $50 \%$ as the animal remained in utero to 33 days. The increase in activity after delivery at 33 days was considerably greater than that following delivery at 29 days.

Activity of cytochrome oxidase is shown in table II and figure 2. Activity increased in the newborn period and agaim the increase occurred following delivery at whatever stage of maturation it was effected. The pattern of increase was similar to that of the mitochondrial $\mathrm{MDH}$ in that activity in utero was constant to 31 days and then decreased between 31 and 33 days. When delivery was effected, the increase in activity was greater at 33 days than at 29, although the level attained after $48 \mathrm{~h}$ did not differ significantly.

\section{Effects of Experimental Hypoxia}

Preliminary experiments were conducted with several litters of animals kept in reduced oxygen tension. Postmature (33 day) animals survived more readily in the chamber than animals delivered at term. The postmature rabbits remained fairly vigorous, with low mortality, in oxygen concentrations measuring usually $6-7 \%$ but occasionally as low as $4.5 \%$. The animals were less active and breathed more rapidly than when kept in room air. They became quite vigorous and appeared healthy when taken out of the chamber at the conclusion of the study.

Livers of some of the animals were mottled with irregular, pale areas $1-3 \mathrm{~mm}$ in diameter. Histologically, these areas showed focal centrilobular cytoplasmic vacuolation (fig. 3 ). The vacuoles did not stain with periodic acid-Schiff's stain as does glycogen. Although sufficient material was not saved for lipid analysis or a fat stain, it was presumed that the vacuolation was due to lipid.

Enzyme activity was determined in only four such postmature animals. The results suggested that the increase of mitochondrial $\mathrm{MDH}$ activity and probably also that of cytochrome oxidase activity was smaller in the hypoxic animals. The increase in cytoplasmic MDH was comparable to that in animals kept in room air.
Table III. Cytochrome oxidase ${ }^{1}$

\begin{tabular}{lcc}
\hline Gestation, day & Birth & $48 \mathrm{~h}^{2}$ \\
\hline 29 & $153 \pm 11^{3}$ & $224 \pm 11^{4}$ \\
& $(10 / 3)^{5}$ & $(13 / 4)$ \\
31 & $159 \pm 16^{6}$ & $249 \pm 22$ \\
& $(12 / 6)$ & $(16 / 6)$ \\
33 & $102 \pm 8^{6}$ & $279 \pm 24^{4}$ \\
& $(9 / 3)$ & $(10 / 5)$ \\
Adult & \multicolumn{3}{c}{$181 \pm 6$} \\
& \multicolumn{3}{c}{$(2)$} \\
\hline
\end{tabular}

1 Activity in micromoles per minute per gram tissue protein.

2 Activities at $48 \mathrm{~h}$ are greater than activity of newborn animals of any gestational age $(P<0.005)$.

${ }^{3}$ Values are mean \pm SEM.

${ }^{4}$ The increase in activity on delivery is greater in animals of 33 days gestation than in animals of 29 days gestation $(P<0.025)$.

${ }^{5}$ Numbers in parentheses are number of animals/ number of litters.

${ }^{6}$ Activity at birth in animals of 33 days gestation is less than activity at birth of animals of 31 days gestation $(P<0.005)$.

\section{Discussion}

The results demonstrated that the postpartum increase of all three enzyme activities studied was regulated by birth itself. The pattern of change of the two mitochondrial enzymes, however, differed from that of cytoplasmic $\mathrm{MDH}$, suggesting that the factors that effect regulation also differ.

Cytoplasmic $\mathrm{MDH}$ activity in utero and its increase following birth were relatively unaffected by the degree of maturation. In contrast, both mitochondrial enzymes were markedly affected by tissue maturity both in the in utero activity and in the increase in activity following delivery. The mitochondrial MDH did not rise significantly following premature delivery, but did increase when delivery was effected at term or postmaturely. Both mitochondrial $\mathrm{MDH}$ and cytochrome oxidase decreased in activity if animals remained in utero beyond term. Even with this decrease, however, the large increase at birth resulted in an activity after $48 \mathrm{~h}$ of postpartum life which was comparable to or greater than that of animals delivered at term.

These findings suggest that if animals remain in utero beyond term, activity of these two mitochondrial enzymes decreases relative to other cell proteins. The subsequent large increases following later delivery indicated that the cell still retained the capacity to in- 
crease activity. Since relative cell composition of the liver remains constant over this period [25], these changes all presumably occur within the same cell elements. The mechanisms of their regulation within these elements are at present unknown.

Other investigators have demonstrated that mitochondrial enzymes and coenzymes increase in the neonatal period $[6,9,11]$. The present study demonstrated that in the case of the two enzymes studied in the rabbit, the increase was a response to the process of birth. Although increases in the number of mitochondria have been reported in the literature [6], it was not possible in the present study to decide whether the change of similar pattern in the two mitochondrial enzymes resulted from a change in number of mitochondria or from changing enzyme activity per mitochondrion.

The component of the birth process responsible for regulation of the enzymes studied is unknown. The differing patterns of change in activity suggest that more than one factor may be operative. Oxygen tension in fetal blood is approximately $20-30 \mathrm{~mm} \mathrm{Hg}$ in most species [5] and rises severalfold at birth to adult levels. This alteration seemed likely to play a role in regulation of the observed rise in activity of the two mitochondrial enzymes, one of which, cytochrome oxidase, is the enzyme in the respiratory chain which utilizes oxygen. In yeast, cytochrome oxidase activity is regulated by environmental oxygen tension [17]; in various developing tissues, studies suggest that this factor may influence activity of certain other enzymes [18, 20, 29].

The pilot study performed was designed to explore means for investigating the role of oxygen tension in regulating perinatal variation in enzyme activity. The design avoided certain confounding features of other investigations of effects of oxygen tension on fetal enzyme activities in which animals apparently breathed room air for several hours after birth and were not fed during a 24-h period of hypoxia [29]. In the current study, animals appeared to survive in oxygen concentrations which should produce a $\mathrm{pO}_{2}$ only somewhat higher than that of most mammalian fetuses [5]. It is not known why survival of the postmature 33-day fetus was better than that of the term 31-day fetus. The vacuolization of hepatic cells was presumably due to lipid. Such lipid might be derived from the dietary lipid of the feeding mixture which has a high fat content (as does rabbit's milk) [4]. Perhaps the reduced oxygen tension impairs the ability of the liver to metabolize lipid. The hypoxic newborn animals did seem to do better when the corn oil in the feeding mixture was reduced in concentration from 10 to $5 \%$ or eliminated entirely. With the altered appearance of the liver and the preliminary nature of the experiment, no definite conclusions can be drawn from the apparently smaller increase in one or both mitochondrial enzyme activities. This study does demonstrate the usefulness of the artificial feeding technique in altering the environment of the newborn animal to investigate control of variation in enzyme activity and other perinatal biochemical and physiologic processes.

Summary

The control of postnatal development of the activities of cytoplasmic and mitochondrial $\mathrm{MDH}$ and of the purely mitochondrial enzyme, cytochrome oxidase, has been studied in rabbit liver. All three of these enzymes increased in activity during the first 2 days of life. Delivery of animals at varying stages of maturation demonstrated that the increase in all cases occurred when delivery was effected and was a result of some aspect of the process of birth itself.

Maturation affected the cytoplasmic enzyme differently than those of mitochondria. Cytoplasmic $\mathrm{MDH}$ was relatively constant in activity in utero and rose approximately the same amount whenever delivery was effected. Both mitochondrial enzymes decreased in activity if animals remained in utero beyond normal term. Their increase after premature delivery was less than that following postmature delivery.

Using the artificial feeding procedure developed for this study, newborn animals were maintained for $48 \mathrm{~h}$ in an hypoxic environment. Preliminary results suggested that development of enzyme activity was affected by hypoxia.

\section{References and Notes}

1. Beaufay, H.; Bendall, D. S.; Baudhuin, R. and DeDuve, C. : Tissue fractionation studies. 13. Analysis of mitochondrial fractions from rat liver by density gradient centrifuging. Biochem.J. 73: 628 (1959).

2. Beaufay, H.; Gampenhout, E. van and DeDuve, C.: Tissue fractionation studies. 12. Intracellular distribution of some dehydrogenases, alkaline deoxyribonuclease and iron in rat liver tissue. Biochem.J. 73: 623 (1959).

3. Burch, H.B.; Lowry, O.H.; Kuhlman, A.M.; Skerjance, M.; Diamant, E.J.; Lowry, S. R. and DIPPE, P. VON: Changes in patterns of enzymes of carbohydrate metabolism in the developing rat liver. J. biol. Chem. 238: 2267 (1963).

4. Gontes, M.E.; Gregory, M.E. and Thompson, S.Y.: The composition of rabbit's milk. Brit.J. Nutr. 18: 583 (1964). 
5. DAwes, G.S.: Fetal and neonatal physiology, a comparative study of the changes at birth (Year Book Medical, Chicago 1968).

6. Dawkins, M.J.R.: Respiratory enzymes in the liver of the newborn rat. Proc.roy. Soc. B. 150: 284 (1959).

7. Dawkins, M.J.R.: Changes in glucose-6-phosphatase activity in liver and kidney at birth. Nature, Lond. 191: 72 (1961).

8. Dawkins, M.J.R.: Glycogen synthesis and breakdown in fetal and newborn rat liver. Ann. N.Y. Acad. Sci 111: 203 (1963).

9. Dawkins, M.J.R.: Biochemical aspects of developing function in newborn mammalian liver. Brit. med.Bull. 22: 27 (1966).

10. DeDuve, C.; Wattiaux, R. and Baudhuin, P.: Distribution of enzymes between subcellular fractions in animal tissues. Adv. Enzymol. 24: 291 (1962).

11. DeVos; M. A.; Wilmink, C.V. and Hommes, F. A.: Development of some mitochondrial oxidase systems of rat liver. Biol. Neonat. 13: 83 (1968).

12. Greengard O. and Dewey, H.K.: Initiation by glucagon of the premature development of tyrosine aminotransferase, serine dehydratase, and glucose6-phosphatase in fetal rat liver. J. biol. Chem. 242: 2986 (1967).

13. Hogeboom, G.H.: Fractionation of cell components of animal tissues; in: S. P. Colwick and N.O. KAPLAN: Methods in enzymology, vol.I (Academic Press, New York 1955).

14. Holt, P.G. and Oliver, I.T.: Factors affecting the premature induction of tyrosine aminotransferase in fetal rat liver. Biochem. J. 108: 333 (1968).

15. Hout, P.G. and Olrver, I.T.: Studies on the mechanisms of induction of tyrosine aminotransferase in neonatal rat liver. Biochemistry $8: 1429$ (1969).

16. Kun, E.: Malate dehydrogenases; in: P.Boyer, M.LARDy and K. MYrback: The enzymes, vol.7, p. 149 (Academic Press, New York 1963).

17. Lindmeyer, A. and Smith, L.: Cytochromes and other pigments of baker's yeast grown aerobically and anaerobically. Biochim. biophys. Acta 93: 445 (1964).

18. Lindy, S. and Rajasalmi, M.: Lactate dehydrogenase isozymes of chick embryo. Response to variations of ambient oxygen tension. Science 153: 1401 (1966).

19. Litwack, G. and Nemeth, A.M.: Development of liver tyrosine aminotransferase activity in the rabbit, guinea pig, and chicken. Arch.Biochem. 109: 316 (1965).

20. Mager, M.; Blatt, W.F.; Natale, P.J. and BLATTEIS, C. M.: Effect of high altitude on lactic dehydrogenase isozymes of neonatal and adult rats. Amer.J. Physiol. 215: 8 (1968).

21. Nemeth, A.M.: Mechanisms controlling changes in tryptophan peroxidase activity in developing mammalian liver. J. biol. Chem. 234: 2921 (1959).

22. Raima, N.C.R. and Suikonen, J.: Factors influencing the development of urea-synthesizing enzymes in rat liver. Biochem.J. 107: 793 (1968).

23. Rreske, M.S.: Preparation and properties of reduced coenzyme Q-cytochrome c reductase (complex III of respiratory chain); in: R.W. EASTBRook and M.E. Pullman: Methods in enzymology, vol. 10 (Academic Press, New York 1967).

24. Roodyn, D. B.: Enzyme cytology (Academic Press, New York 1967).

25. SMrтH, G.H. : Regulation of malate dehydrogenase in the liver of newborn rabbits maintained by a convenient new technique of artificial feeding. Biol. Neonat. 12: 219 (1968).

26. Smith, L.: Spectrophotometric assay of cytochrome c oxidase. Meth. biochem. Anal. 2: 427 (1955).

27. Stave, U.: Age-dependent changes of metabolism. I. Studies of enzyme patterns of rabbit organs. Biol. Neonat. 8: 128 (1964).

28. Stave, U.: Age-dependent changes of metabolism. II. Influences of hypoxia on tissue enzyme patterns of newborn and adult rabbits. Biol. Neonat. 8: 114 (1965).

29. Stave, U.: Age-dependent changes of metabolism. III. The effect of prolonged hypoxia upon tissue enzyme activities of newborn and adult rabbits. Biol. Neonat. 11: 310 (1967).

30. Swick, R.W.; Stange, J. L. and Nance, S. L. : The heterogeneous distribution of mitochondrial enzymes in normal rat liver. Biochemistry 6: 737 (1967).

31. Wharton, D. C. and Tzagoloff, A.: Cytochrome oxidase from beef heart mitochondria; in: R.W. EAstbrook and M.E. Pullman: Methods in enzymology, vol. 10 (Academic Press, New York 1967).

32. Wicks, W.D.: Induction of tyrosine- $\alpha$-ketoglutarate transaminase in fetal rat liver. J.biol. Chem. 243: 900 (1968).

33. Wraks, W.D.: Tyrosine- $\alpha$-keto-glutarate transaminase: Induction by epinephrine and adenosine3'5'-cyclic phosphate. Science 190: 997 (1968).

34. Wickxnson, J.H.: Isoenzymes, p. 84 (Lippincott, Philadelphia 1966).

35. Yeung, D. and Oliver, I.T.: Development of gluconeogenesis in neonatal rat liver. Effect of premature delivery. Biochem. J. 105: 1229 (1967).

36. Yeung, D. and Oliver, I.T.: Factors affecting the premature induction of phosphopyruvate carboxy- 
lase in neonatal rat liver. Biochem.J. 108: 325 (1968).

37. Yeung, D. and Olrver, I.T.: Induction of phosphopyruvate carboxylase in neonatal rat liver by adenosine 3'5'-cyclic monophosphate. Biochemistry 7: 3231 (1968).

38. Yonetani, T.: The a-type cytochromes; in: P. Boyer, H. LARDY and K. MYrback: The enzymes, vol. 8 (Academic Press, New York 1963).

39. Beckman Instruments, Inc., Fullerton, CA.

40. From horse heart, Sigma Chemical Company, St. Louis, MO.

41. Model RC2-B, SS34 bead, Ivan Sorvall, Inc., Norwalk, GT.
42. Model L2, mo. 40 herd, Beckman Instruments, Inc., Spinco Division, Palo Alto, CA.

43. The author thanks Mrs. Mary Alice Sennetr for her skillful technical assistance.

44. Supported in part by Public Health Service Research Grant no.HD 02182 and by Research Career Development Award no. 5 K03 HD35178. 45. Request for reprints should be addressed to: C.H.Smith, M.D., Department of Pathology, Washington University School of Medicine, St. Louis, MO 63110 (USA).

46. Accepted for publication November 7, 1969. 